\title{
ACERCA DEL AVE FÉNIX EN LAS TRADICIONES ISLÁMICAS
}

\author{
ON THE PHOENIX IN ISLAMIC TRADITIONS
}

\author{
Pedro Buendía \\ Universidad de Salamanca
}

\begin{abstract}
En medios culturales occidentales, ha sido costumbre identificar la leyenda árabe del ave gigante 'Anqā' Mugrib con el mito del ave Fénix tal y como se conoce en las fuentes grecolatinas. Dicha identificación se basa casi exclusivamente en la presunta procedencia del Fénix de Arabia. Sin embargo, un detallado análisis de los textos muestra de forma clara que ambos mitos son esencialmente diferentes y describen a dos aves que formal y estructuralmente son completamente distintas. Aunque la leyenda de la 'Anqā' se contamina en algunos textos con el mito de la vetusta edad del Fénix, las literaturas árabe y persa conocen un ave llamada qaqnus cuyas características concuerdan esencialmente con las del mito grecolatino del Fénix. Esta ave qaqnus, además, suele ser mencionada como un ave diferente y aparte de la 'Anqā'.
\end{abstract}

Palabras clave: 'Anqā', 'Anqā' Mugrib, ave Fénix, Simurg, Sìmorg, Rujj, Roc, grifo, qaqnus, cisne, aves mitológicas, zoología fantástica, paradoxografía, mitología comparada.
In Western cultural milieus it has been customary to identify the Arabian legend of the giant bird 'Anqā' Mugrib as a version of the mythical Phoenix known from Greco-Latin sources. Linking these two together is based almost exclusively on the Phoenix supposedly coming from Arabia. However, a detailed analysis of the sources clearly shows that the two myths are essentially different, and describe two birds that are completely divergent in shape, mythical development and textual significance. Although the 'Anqā' has merged in some texts with the myth of the Phoenix, because of its long life, Arab and Persian literature also speak of a bird known as qaqnus, which has essentially the same characteristics as the one in the Greco-Latin myth of the Phoenix. The qaqnus bird, in addition, is usually mentioned as another bird along with the 'Anq $\bar{a}$ ', making clear that it is different and separate from this.

Key words: 'Anqā', 'Anqā' Mugrib, Phoenix, Simurg, Sìmorg, Rukhkh, Rukh, griffin, qaqnus, swan, mythological birds, imaginary zoology, paradoxography, comparative mythology.

Contra lo que puede parecer, la presencia del ave Fénix en las tradiciones islámicas orientales es infrecuente, y debe ser revisada con especial cuidado. Ello se debe a la inveterada (y acrítica) costumbre de asimilarla a otra de las aves mitológicas más populares y relevantes del folklore árabe, el llamado 'Anqū' Mugrib o 'Anqū' a 
secas. En las siguientes líneas intentaremos explicar que ambas criaturas pertececen a mitos esencialmente distintos, aunque contaminados en aspectos puntuales. Se trata, por decirlo llanamente, de dos aves diferentes que no deben ser confundidas, y cuya andadura legendaria ilustra un importante capítulo de la historia simbólica del oriente mediterráneo.

En épocas modernas, no son pocas las obras lexicográficas, zoológicas y de vario género que identifican a la 'Anqu' ' con el ave Fénix ${ }^{1}$. Dicha identificación, sin embargo, se establece sobrepasando los límites de cualquier parecido razonable. Pesa en ella la tendencia general de toda cultura de asimilar a los suyos los términos mitológicos que no le son propios. Para intentar ilustrar el escaso fundamento de esa identificación, repasaremos en primer lugar los textos esenciales de ambos mitos, y a continuación examinaremos los documentos de la cultura islámica que citan específicamente al ave Fénix.

\section{El ave Fénix y la 'Anqū': dos parientes muy lejanos}

El mito del ave Fénix, aunque tradicionalmente adscrito al Oriente, tiene una elaboración y desarrollo esencialmente grecolatinos. Sus principales fuentes sitúan su origen en Egipto y Arabia. En su mención más antigua, Heródoto confiesa no haberlo visto «más que en pintura $»^{2}$. Según sus noticias, el Fénix tiene la forma y tamaño de un águila, con plumas rojas y doradas. Cada quinientos años se desplaza desde Arabia hasta el santuario de Helios, en Egipto, portando el cadáver de su progenitor, que previamente ha envuelto en un huevo de mirra. Plinio señala que está consagrado al sol, y añade variedad al color de su plumaje: púrpura y azul, con un penacho en la cabeza. Cada quinientos cuarenta años, el Fénix construye un

${ }^{1}$ Cf., aparte de los varios ejemplos nombrados en nota al pie a lo largo de este trabajo, y por centrarnos en el ilustrativo campo de la lexicografía: «Ave fénix, grifo [mit.]» (Corriente, F., Diccionario Árabe-Español, Madrid, 1986, s.v.); «Ave fénix [mit.]; grifo [mit.]» (Cortés, J., Diccionario de árabe culto moderno, Madrid, 1996, s.v.); «Griffin; phoenix; rare in its kind» (Steingass, F., A Learners Arabic-English Dictionary, Beirut, 1987, reimpr. Londres, 1884, s.v. "anqā" [sic.]); «Animal légendaire entre phénix et griffon» (Premare, A.-L. de, Dictionnaire Arabe-Français, París, 1996, s.v.); «Griffone o fenice (animali favolosi)» (Traini, R., Vocabolario Arabo-Italiano, Roma, 1969, s.v.) Passim.

${ }^{2}$ Heródoto, Historia, C. Schrader (trad.), Madrid, 1979, II, 73. 
nido de ramas de casia e incienso y muere en él; de sus cenizas nace un gusano que se transforma en un nuevo polluelo del Fénix ${ }^{3}$. Tácito señala varias tradiciones tocantes a su edad, que oscilan entre los quinientos y los mil cuatrocientos sesenta y un años. Al renacer, el Fénix transporta el cadáver de su padre hasta el altar del sol en Egipto y lo quema ${ }^{4}$. Filóstrato destaca su carácter único, «emanado de los rayos del sol y brillante de oro» ${ }^{5}$.

La tradición literaria posterior, que continuará hasta los padres de la Iglesia y los bestiarios medievales, añadirá a las líneas maestras del mito pequeños detalles (procedencia del ave, coloración y algo más o menos de tamaño) así como diversas «interpretaciones» sobre su significado; pero sin alterar en lo esencial el relato expuesto en las principales fuentes ${ }^{6}$. Nos referimos a las dos características esenciales del mito del Fénix: su renacer periódico y su desplazamiento a Egipto al final o al principio de cada espacio vital. Queda claro que se trata de un mito de naturaleza solar, difusamente asociado al cumplimiento de algún tipo de ciclo cósmico. Tradicionalmente se ha especulado con la posibilidad de que este Fénix mencionado por los autores grecolatinos, sea un trasunto del ave que los antiguos egipcios llamaron Benu. Dicha ave, representada en forma de garza que nacía de una llama sobre el árbol sagrado de la persea, fue usada desde épocas tempranas en los cultos de Heliópolis como encarnación del sol y símbolo de la resurrección ${ }^{7}$. Así, los 1460 años de vida que Tácito atribuye al Fénix se corresponderían con los de cada evo Sótico o Gran Año egipcio, con cuya venida se creía que nacía una nueva ave de este género ${ }^{8}$. Sea cierta o no esta

${ }^{3}$ Plinio, Historia Natural, Madrid, 2003, X, 2, 3-5.

4 Tácito, Anales, Madrid, 1991,VI, 28.

${ }^{5}$ Filóstrato, Vida de Apolonio de Tiana, A. Bernabé Pajares (trad.), Madrid, 1992, III, 49.

${ }^{6}$ Sobre el mito del ave Fénix, cf. Anglada Anfruns, A., El mito del Ave Fénix, Barcelona, 1983; Van Den Broek, R., The Myth of the Phoenix, According to Classical and Early Christian Traditions, Leiden, 1972; Fabrizio-Costa, S. (ed.), Phénix: mythe(s) et signe(s), Actes du colloque international de Caen (12-14 octobre 2000), Berna, 2001.

7 Bunson, M.R., Encyclopedia of Ancient Egypt, Nueva York, 2002, s.v. "Bennu (Bnr, Bnrt)".

${ }^{8}$ Van Den Broek, The Myth of the Phoenix, 72. No obstante, dicha identificación es puesta en duda por el propio autor: «There are no indications that ideas about the benu's manner of dying and revival were developed in ancient Egypt. In the Classical view, death and resurrection form the core of the phoenix myth: the old phoenix dies and the young phoenix generates itself from its decaying body, or the old bird burns 
identificación, nos interesa destacar ahora este carácter cíclico y solar del mito del Fénix, junto a su tamaño nada extraordinario (de las hechuras de un águila aproximadamente) tan distinto, como veremos, a la naturaleza esencial del ave llamada 'Anqū' Mugrib.

La descripción del mito de la 'Anqā', en efecto, es muy diferente ya desde sus primeras menciones en la literatura árabe. La relación más detallada, aportada por al-Mas' 'ūdī según un hadiz atribuido a Ibn 'Abbās, afirma que la 'Anqū' fue creada por Allāh «en los primeros tiempos» y reunía «lo mejor de todas las aves» en su maravilloso plumaje multicolor. Tenía rostro humano y un recio pico «a la hechura del pico de las águilas», con cuatro alas por cada extremo y manos dotadas de garras. Allāh creó después una hembra a su imagen y entonces susurró al oído de Moisés: «He dado vida a un pájaro maravilloso. He creado un macho y una hembra y les he dado por alimento las bestias que merodean Jerusalén. A ambos los he ligado con lazos de familiaridad contigo para que sean testimonio de la preeminencia que te distingue entre los hijos de Israel». A partir de ese momento, la pareja de aves 'Anqu' 'se reprodujo sin cesar «de guisa que su progenie se multiplicó» y comenzaron a ocasionar estragos entre los humanos, «trasegando no sólo bestias, sino niños y acémilas, hasta que apareció entre la tribu de los Banū 'Abs un profeta de los que llegaron entre Jesús y Mahoma, llamado Jālid b. Sinān. Entonces la gente fue a quejarse de las desgracias que cometía aquella ave con sus criaturas, y Jālid pidió al Señor que pusiera fin a la estirpe de la 'Anqu' '. Hízolo Dios, y ya de ella tan sólo quedó la imagen, representada en tapices, alfombras y otros lugares» ${ }^{9}$.

itself and the young one arises from its ashes. It is clear that there are certain parallels and relationships between the benu and the phoenix, but it is not possible to demonstrate that the Classical views were based on the Egyptian, as some authors have assumed», Van Den Broek, The Myth of the Phoenix, 20. Cf. asimismo Lecocq, F., "Les sources egyptiennes du mythe du Phénix", Cahiers de la Maison de la Recherche en Sciences Humaines, 41 (2005), 211-266.

${ }^{9}$ Al-Mas' $\mathrm{u} d \overline{1}$, Murūŷ al-dahab wa-ma'ādin al-ŷawhar, 1347-48 [IV, 18-IV, 21], Barbier de Meynard y Pavet de Courteille (eds.), Ch. Pellat (rev.), Beirut, 1966, II, 368-369. La noticia la repiten al-Zamajšarī (Rabī' al-abrār wa-nuṣūs al-ajbār, S. al-Ni'mà (ed.), Bagdad, 1410 H., IV, 457), al-Ibšīhī, (al-Mustatraf fi kull fann mustazraf, M. M. Qumayhạa (ed.), Beirut, 1993, cap. 62, 389) y al-Ta'ālibī (Timār al-qulūb, M. Abū-l-Faḍl Ibrāhīm (ed.), El Cairo, 1985, n. ${ }^{\circ}$ 729, 450). Sobre la presencia de la 'Anq $\bar{a}$ ' como motivo en los tapices, cf. Serrano Niza, D., "La naturaleza en el telar andalusí", en C. Álvarez de Morales, Ciencias de la Naturaleza en Al-Andalus, Granada, 2001, 237-257. 
Como puede apreciarse, estamos en presencia de un mito de tipo cosmogónico, sutilmente asociado a la creación del mundo y la civilización, y hábilmente encauzado en un marco de «legitimidad profética» en virtud del cual la preeminencia divina se traslada desde los hijos de Israel hasta los hijos del desierto de Arabia. No hay aquí renacimiento ni cenizas; no hay cumplimiento de ciclos ni relación con el sol o santuario solar alguno; no hay descendencia ni vida eterna para la 'Anq $\bar{a}$ ', cuyo carácter es dañino y cuyo tamaño es tan grande que puede arramblar con «niños y acémilas». Además, la 'Anqa' ' es un animal de hechuras muy diferentes a las del Fénix: este tiene la forma y tamaño aproximados de un águila, y apenas puede cargar con el cadáver de su progenitor; aquella, en cambio, tiene rostro humano y cuatro alas por cada flanco. Por terminar de perfilar esta primera aproximación, señalemos que, ni formal ni estructuralmente, coinciden ambos mitos; y por lo tanto será oportuno preguntarse por qué razón han sido tan frecuentemente asimilados.

Las primeras aproximaciones a la 'Anq $\bar{a}$ ' en la literatura árabe parecen deberse a al-Ŷāhiz, quien, en un pasaje dedicado a las especulaciones sobre el rinoceronte, arremete contra las creencias relacionadas con esta ave legendaria y la identifica claramente con el Sìmurg de la epopeya persa, el pájaro gigantesco y poderoso que custodia y protege al héroe Zāl en el Libro de los Reyes de Firdūsī:

Muchos son los que niegan que haya en el mundo un animal llamado karkaddan ['rinoceronte'], afirmando que es del percal de la 'Anqā' Mugrib, aunque a esta la hayan visto retratada en los tapices de los reyes, para quienes su nombre es, en persa, Simark [i.e. Simurg ], que es como decir "son treinta pájaros», pues en persa la palabra $s \bar{l}$ significa 'treinta', y murg es 'pájaro' en árabe ${ }^{10}$.

Este Simurg es heredero del ave grandiosa y primordial que en el Avesta recibe el nombre de Saēna ${ }^{11}$, y en los textos pahlavíes se convertirá en Sēnō mūrūk («el pájaro Sēnō») ${ }^{12}$ antes de culminar su

10 Al-Ŷāhiz, Kitāb al-hayawān, 'A-.S.M. Hārūn (ed.), Beirut, s.d., VII, 120-121.

${ }^{11}$ Zend-Avesta, J. Darmesteter (trad.), en M. Müller, Sacred Books of the East, Delhi, 1998, II, (reimpr. 1887), Yast XIII (Farvardīn Yast), XXV, 97 (pág. 203); Yast XIV (Bahrām Yast) XV, 41 (pág. 242). Cf. Casartelli, M.L.C., "Çyena-Sîmurgh-Roc. Un chapitre d'évolution mythologique et philologique", en Compte Rendu du Congres Scientifique International des Catholiques, París, 1891, VI, 80.

12 Bundahis, XIV, 23-4, p. 50 y n. 2; XVIII, 1-11, pp. 65-67; Zād-Sparam, VIII, 3, p. 176. Todas las referencias en West, E.W., Pahlavi Texts, en M. Müller, Sacred Books of the East, Delhi, 1998 (reimpr. 1887). 
evolución onomástica en el persa Simurg. Dicha ave reside en el centro del mundo, asociada a Gōkard, el árbol primordial que contiene todas las semillas del universo, diseminadas por la tierra cuando el colosal pájaro bate sus alas. La identificación que al-Ŷāḥiz hace de ambas aves, 'Anqā' y Simmurg, no es baladí, pues se convertirá en moneda corriente en la literatura árabe y persa posteriores. Así lo hará al-Ṭabarī al relatar las tradiciones persas relacionadas con Isfandiyār ${ }^{13}$ y al-Maqdisī en las de Rustam y Kay Kāwus ${ }^{14}$; también al-Ta 'Taalib̄i, en su versión de la epopeya persa, designará al Sìmurg con el nombre de 'Anqā' ${ }^{15}$; así como al-Bagdādīin, Mustawfí ${ }^{17}$ y el Qahramān-nāma, ciclo épico del folklore persa y turco donde el héroe Țahmūrat conversa con un Simmurg llamado por el nombre de 'Anqa $\bar{a}^{\prime}{ }^{18}$. Nos interesa subrayar esta identificación que árabes y persas siempre mantuvieron entre ambas criaturas porque tampoco el Sìmurg ni sus antecesores Saēna o Sēnō mūrūk guardan grandes similitudes con las características esenciales del ave Fénix, que nombrábamos al comenzar este trabajo y que son universalmente conocidas.

Sucesivas menciones del ave 'Anqā' en la literatura árabe terminarán de perfilar su retrato. Ibn Durayd introduce una etimología para su nombre, más tarde repetida por al-Ŷawharī, al-Rāgib alIṣfahānī, Ibn Manẓūr, al-Ibšīhī, al-Bagdādī y al-Zabīdī: al- 'Anqū' significa «la de cuello largo», «cuellilarga» (Ṭawìlat al-'unq), noticia a veces acompañada con la mención de una mancha o rodal

${ }_{13}$ Al-Tabarī, Tārīj al-rusul wa-l-mulūk, M. Abū-l-Faḍl Ibrāhīm (ed.), El Cairo, s.d., I, [680], 563; trad. ingl. de M. Perlmann en The History of Al-Tabarī, Nueva York, 1987, IV, [678], 75.

${ }_{14}$ Al-Maqdisī, Kitāb al-bad' wa-l-tārīj, Cl. Huart (ed. y trad.), Le Livre de la Création et de l'Histoire, París, 1903, III, 148-9 del texto árabe (la versión francesa —pág. 153 - traduce al-'Anqā̄' por "phénix").

${ }_{15}$ Al-Ta'ālibī, Gurar ajbār mulūk al-Fārs wa-siyari-him, H. Zotenberg (ed. y trad.), Histoire des Rois de Perse, París, 1900, 69 y sigs., 316-19; el relato de Sām y Zāl figura asimismo en Basset, R., 1001 contes, légendes et recits arabes, París, 1924, n. ${ }^{\circ}$ 40, 165, con el título "L'enfant élevé par un griffon".

16 Al-Bagdādī, Jizānat al-adab wa-lubb lubān lisān al-'arab, 'A-.S.M. Hārūn (ed.), El Cairo, 1986, VII, 134-136: «A este pájaro [la 'Anqā'] se le llama en persa Simurg».

${ }_{17}$ Stephenson, J., The Zoological Section of the Nuzhatu-l-Qulüb of Hamdullāh alMustaufí al-Qazwīnī, Londres, 1928, 112 y 79 de la trad., s.v. “"Anqā̄”.

${ }^{18}$ Cf. Casartelli, "Çyena-Sîmurgh-Roc", 82 (apud D'Herbelot, Bibliographie Orientale, París, 1697, 234, s.vv. Thahmurath, Caherman). Véase asimismo EI ${ }^{2}$, J.T.P. de Bruijn, s.v. "Kahramān-nāma". 
blanco situados alrededor de su cuello ${ }^{19}$. Hacia las postrimerías del siglo XII, su leyenda se encuentra ampliamente extendida por el mundo islámico, pues protagoniza una de las maqāmāt de Abū-lṬāhir al-Saraqusṭi en al-Andalus ${ }^{20}$, así como un episodio de la leyenda de Buda en la versión árabe del Libro de Bilawhar y $B \bar{u} \underline{d} \overline{a s} f^{21}$. Asimismo, en el apólogo de la Disputa de los animales contra el hombre de las Rasā'il Ijwān al-Ṣafā', el ave 'Anqā' aparece descrita como soberana de las aves de presa, con el halcón por heraldo. Vive en lejanos horizontes y es el ave más grande que existe: «Cuando se abalanza por el aire en su vuelo tiemblan las montañas por la intensa agitación del viento al ser sacudido por sus alas y arrebata los búfalos y el elefante de la superficie del suelo cuando va volando» ${ }^{22}$. También rescata náufragos y navíos a la deriva ${ }^{23}$. Al-Qazwīn̄i ofrecerá un testimonio parejo: «Cuando vuela, se oye salir de sus plumas un clamor como el de una ventolera repentina, o como el ruido que hacen los árboles cuando los sacude un vendaval»» ${ }^{24}$.

La relación de la 'Anqā' con los mares y remotos parajes no es casual. Precisamente en estas fechas aparecen en la literatura árabe las primeras menciones de la gigantesca ave Roc (Rujj), asociada a las navegaciones, las tempestades y los lejanos confines del oriente. Según los célebres relatos de Buzurg b. Šahriyār y Abū Ḥāmid ${ }^{25}$, el

${ }^{19}$ Ibn Durayd, Ŷamharat al-luga, R. Munīr Ba'lbakī (ed.), Beirut, 1987, s.v. "“nq"; al-Rāgib al-Ișfahān̄̄, Muhādarāat al-udabā', El Cairo, 1908, 1485; al-Ŷawharī, al-Șihāh fìl-luga, A. 'Abd al-Gaffūr 'Ațtār (ed.), Beirut, 1984, s.v. "“nq"; Ibn Manz̄ūr, Lisà̄n al'arab, 'A.-A. 'Alī al-Kabīr et alii (ed.), El Cairo, s.d., s.v. "“nq"; al-Ibš̄̄î̄, al-Mustatraf, 389; al-Bagdādī, Jizānat al-adab, VII, 135; al-Zabīdī, Tāŷy al-'arūs, 'A-S.A. Farrāŷ (ed.), Kuwait, 1965, s.v. "“nq".

${ }^{20}$ Abū-1-Ṭāhir al-Saraqusṭī, al-Maqāmāt al-luzūmiyya/Las sesiones del Zaragocí. Relatos picarescos (maqāmāt) del siglo XII, I. Ferrando (trad.), 1999, maqāma XXXVI (llamada en la trad. «Del ave Fénix» por el original 'Anqā' Mugrib), 187-196.

${ }^{21}$ Le Livre de Bilawhar et Bū (trad.), Ginebra, 1971, 153-155.

${ }_{22}$ Rasā'il Ijwān al-Ṣafā' wa-Jillān al-Wafā', B. al-Bustānī (ed.), Beirut, s.d., II, 293294. Trad. esp. Tornero, E., La disputa de los animales contra el hombre (traducción del original árabe de la disputa del asno contra Fray Anselmo Turmeda), Madrid, 1984, 133 (con traducción del árabe 'Anqā' o 'Anqū' Mugrib por «Ave Fénix»).

${ }_{23}$ Rasā'il Ijwān al-Ṣafā', 262; Tornero, La disputa de los animales, 97.

${ }^{24}$ Al-Qazwīn̄̄, 'Aŷà'ib al-majlūqāt, Teherán, s.d., (impresa junto con Hayāt alhayawān de al-Damīrī), 281.

${ }^{25}$ Al-Rāmahurmuz̄̄ (Buzurg b. Šahriyār), Kitāb 'aŷā'ib al-Hind, barri-hā wa bahrihà wa ŷazā'iri-hā (Livre des merveilles de l'Inde), M. Devic (trad.), P.A. Van der Lith 
ave Roc pone huevos como montañas y transporta náufragos inadvertidos, anticipando así las aventuras que el universal Sindbād el Marino vivirá en el segundo de sus viajes. Es evidente que - si no son la misma - hacia los albores del s. XIII las leyendas de 'Anqā' y Roc se encuentran fuertemente identificadas, y entreveradas además por elementos de otras figuras legendarias de aves, en consonancia con el extraordinario apogeo que la literatura paradoxográfica o de ' $a \hat{y} \bar{a}$ ' $i b$ había empezado a adquirir. Este extremo lo confirmarán los testimonios de al-Qazwīn̄̄ y al-Damīì̄, quienes de nuevo mencionan su colosal tamaño: la 'Anqā' (tal y como el Roc) «pone huevos como montañas» ${ }^{26}$, y «es capaz de arrebatar un elefante como arrebata un ratón el gavilán ${ }^{27}$. Al-Qazwīnī señala que debido a los estragos y rapiñas que ocasionaba entre la gente - pues llegó incluso a arrebatar una novia recién desposada - la 'Anq $\bar{a}$ ' es desterrada a «una de las islas del océano, bajo la línea del ecuador». Allí se convertirá en la reina de los animales del lugar, a los cuales alimenta con los despojos de su caza: «elefantes, peces grandes o dragones». Añade a ello este autor el relato de un mercader que, extraviado por el océano, divisa «una gran mancha negra como una nube umbría» que resulta ser el ave 'Anqa' ' Mugrib. La nave - prosigue el navegante citado por al-Qazwīnī - se aproxima hasta cobijarse bajo la sombra del ave gigantesca, que los reconduce al rumbo deseado ${ }^{28}$.

El relato del ave descomunal enclavada en el océano y que pone huevos colosales no sólo participa de la leyenda común del mencionado Roc, sino también del Bar Yokani talmúdico, que en Bekoroth $57 \mathrm{~b}$ arroja a la Tierra un huevo cuyo contenido «empantanó dieciséis ciudades y destruyó trescientos cedros» ${ }^{29}$. En Babá Batrá $73 b$

(texto árabe), Frankfurt, 1993, 12-14; Abū Ḥāmid al-Garnātị, Tuhfat al-albāb (El regalo de los espiritus), A. Ramos (trad.), Madrid, 1990, 73-4. Aunque en el relato de Buzurg no aparece el ave mencionada por su nombre y se atribuye a Abū Ḥāmid la primera mención, no cabe duda de que se trata de la misma ave.

${ }^{26}$ Al-Damīrī, Hayāt al-hayawān al-kubrà, Teherán, s.d., (impresa junto con 'Âya'ib al-majlūqāt de al-Qazwīnī), s.v. “'Anqā̄”, II, 86-90.

27 Al-Qazwīn̄i, 'Âyā'ib al-majlūqāt 281.

${ }_{28}$ Al-Qazwīnī, 'Âȳa'ib al-majlūqāt. Sobre la figura del Rujj, todavía es útil la bibliografía citada por Vernet, J., "Rujj = Aepiornis Maximus", Tamuda, 1 (1953), 102-105; cf. asimismo Arcas Campoy, M., "El Rujj, las avestruces y la arqueología en el sureste español”, en E. García Sánchez y C. Álvarez de Morales, Ciencias de la Naturaleza en Al-Andalus, Granada, 2004, 195-205; $E I^{2}$, U. Marzolph, s.v. "Rukhkh".

${ }^{29}$ Otras referencias talmúdicas sobre Bar Yokani en Sukkah 5b y Yoma 80a. 
también aparece en el transcurso de una travesía un pájaro "cuyas patas estaban en el agua y cuya cabeza alcanzaba los cielos», clavado como la 'Anqā' en medio del océano, en un lugar de aguas tan profundas que «un carpintero hizo caer su azuela allí hace siete años, y todavía no ha tocado el fondo» ${ }^{30}$.

Otros datos de diversa naturaleza y procedencia, pero relativamente próximos en el tiempo, aportan nuevas coincidencias a la leyenda del ave colosal. En la Navegación de San Brandán se muestra un ave terrorífica — esta vez llamada grifo - que se apresta a devorar a los navegantes que acompañan al santo padre ${ }^{31}$. También Benjamín de Tudela menciona la leyenda de los marinos que para escapar a las tormentas del mar de la China se esconden en cueros de reses, para que «la gran águila llamada grifo» los atrape en sus garras y los transporte a tierra firme ${ }^{32}$. El mismo procedimiento se relata en el segundo viaje de Sindbād, con el ave Roc como protagonista. Y el propio Roc aparecerá pintado en los viajes de Marco Polo como «tan grande y tan poderoso que coge un elefante y lo lleva por el aire muy alto sin ayuda de ningún otro pájaro» ${ }^{33}$. La misma argucia de salvación, en fin, se relata en la tradición oral bereber en una fábula sobre el rey Salomón en la que una princesa es salvada de las garras de la 'Anqa' ' tras esconderse dentro del pellejo de un caballo y ser arrastrada por ella ${ }^{34}$.

En un excelente estudio sobre la figura de 'Anqu' ' Mugrib, K. Zakhariya afirma que, aunque su existencia parece ser antigua entre los árabes, esta ave fue «construida en referencia explícita al Simurg persa», pues no tenemos datos acerca de ella anteriores al siglo $\mathrm{IX}^{35}$. Esto es cierto sólo en una pequeña parte, pues, si no en

30 Cf. Aggadoth du Talmud de Babylonie. Source du Jacob / 'Ein Yaakov, París, 1982, 957; Ginzberg, L., Legends of the Jews, t. I, p. 29 y n. 131 en vol. V, p. 47.

${ }_{31}$ Navegatio Sancti Brendani Abbatis, J.M. Álvarez Flórez (trad.), Madrid, 1995, 39.

32 Libro de viajes de Benjamín de Tudela, J.R. Magdalena Nom de Deu (ed.), Barcelona, 1982, 113.

33 Marco Polo, Libro de las maravillas, M. Armiño (trad.), Madrid, 2000, 505-507; Santaella, R. de, El Libro de Marco Polo, J. Gil (ed.), Madrid, 1987, cap. 40, 158159.

34 Basset, R., Contes Populaires Berbères, París, 1887, n. ${ }^{\circ}$ 13, 27. Modificamos la traducción «griffon» por su original 'Anqā', como el propio Basset hace constar (n. 23, 150). Cf. Asimismo 1001 contes, n. 40 ("L'enfant élevé par un griffon"). La historia es mencionada también por al-Maqdis̄̄, Kitāb al-bad'wa-l-tārīj, III, 154.

35 Zakhariya, K., "La 'anqâ'. ¿Quelle place pour le phénix dans le monde arabomusulman classique?", en Fabrizio-Costa, Phénix, 118. 
la literatura árabe, en la literatura siríaca tenemos suficientes muestras que acreditan la existencia de un mito formal y funcionalmente idéntico al de la 'Anqa' '. Nos referimos a los comentarios de los padres de la iglesia caldea desde san Efrén en adelante, ya exhumados con mano maestra por F. Nau en 1929, hasta llegar a autores coetáneos de al-Mas' đùd̄̄ y al-Qazwīn̄i como Bar Bahlul y Bar Hebraeus ${ }^{36}$. Estos autores describen a un pájaro gigantesco al que a veces llaman «el pájaro elefante», por ser capaz de arramblar con los elefantes por los aires para comérselos, así como de ocasionar muchas calamidades entre los hombres. Dicho pájaro parece tener su nido en la India y, tal y como hará la 'Anqa' ', al agitar sus alas remueve los bosques y arranca los árboles. De hecho, Bar Bahlul identifica expresamente el mentado "pájaro elefante» con la 'Anqā', y Jacobo de Edesa describe un modo de cazarlo idéntico al aportado más tarde por al-Damīī para la 'Anqa ': un cazador se esconde entre dos pieles de toro atadas y rellenas con piedras, dispuestas a modo de cebo; cuando el pájaro intenta capturarlos el cazador sale del interior y lo mata ${ }^{37}$. En otro lugar hemos dedicado algunos esfuerzos a documentar la existencia continua del mito de un monstruo alado y terrible desde los textos sumerios hasta la literatura árabe medieval, cuyas manifestaciones abarcarían el binomio Imdugud / Anzu sumerio y acadio, el grifo griego, el ave Garuda de la mitología védica, el Bar Yokani talmúdico y la tríada 'Anqā' / Simmurg / Roc. Esta bestia inquietante es el superviviente de un Chaoskampf cosmogónico, cuya pervivencia constituirá una desafiante prueba de la grandeza de la divinidad, que acaba derrotándola y sometiéndola a su volun$\operatorname{tad}^{38}$.

Los datos expuestos, pues, nos muestran claramente que a partir del s. X las tradiciones sobre un ave gigantesca que vive en remotos confines, que hace estragos entre animales y hombres, que pone huevos gigantescos y que de alguna manera se asocia a las fuerzas

${ }^{36}$ Nau, F., "Étude sur Job XXXIX, 13 et sur les oiseaux fabuleux qui peuvent s'y rattacher", Journal Asiatique, (1929), 193-236. 86-90.

${ }_{37}$ Cf. Nau, "Étude sur Job", 205; al-Damīrī, Hayāt al-hayawān, s.v. "Anqāa”,

${ }^{38}$ Cf. Buendía, P., 'Anqā' Mugrib: el ave cósmica en las tradiciones orientales. Tesis doctoral, Madrid, Universidad Autónoma, 2003; Buendía, P. y Mirones Lozano, E., "Se esconde en Job 39:13. Una revisión crítica de su historia hermenéutica y de las teorías sobre su significado", Revue Biblique, 117 (2010), 223-247. 
maravillosas y desconocidas de la creación, se encuentran largamente difundidas en el folklore y la literatura de amplias zonas del Mediterráneo y Oriente próximo.

Como hemos visto, esta leyenda no guarda grandes similitudes con el antiguo mito del ave Fénix, cuyas características esenciales son el renacimiento y muerte cíclicos acompañados de un largo desplazamiento al templo del sol en Heliópolis. Sin embargo, a continuación veremos cómo existen elementos de esta ave confundidos entre algunas de las descripciones de la 'Anqu', y cómo ambas leyendas tendrán algún desarrollo paralelo. Junto al pretendido origen árabe del Fénix, serán estos elementos los que contribuyan a «fabricar» la identificación de las dos criaturas aladas.

\section{Fénix y 'Anqāa': caminos cruzados}

En la última parte de su descripción de la 'Anqā', al-Qazwīnī incrusta una serie de detalles insólitos que sí guardan relación directa con la leyenda del Fénix:

Hay quien ha dicho que la 'Anqa' ' vive mil setecientos años, y que se ayunta cuando alcanza los quinientos. Cuando le llega el momento de la puesta, siente un dolor punzante [...] Entonces sale de ella el huevo y lo empolla [...] A los ciento veinticinco años hace eclosión el huevo. Al crecer, si el pollo es hembra, la 'Anqa' atrapa mucha madera y su macho le prende fuego con su pico. Arde el maderamen, y entonces la 'Anqa' ' se mete en el fuego y se quema, y así la pollita hembra queda como esposa del macho. Si por el contrario el pollo es macho, es el macho de la 'Anq $\bar{a}$ ' el que se echa al fuego, quedando entonces el polluelo como esposo. Sobre la 'Anqā', en fin, se han dicho cosas muy raras -más incluso que estas que hemos contado-, pero no están acreditadas por gente de fiar, conque a ese criterio nos atenemos ${ }^{39}$.

Ciertamente, los 1700 años de vida que aquí se atribuyen a la 'Anqū' recuerdan en cierto modo a los 1460 años que Tácito había atribuido al Fénix. Asimismo, los quinientos años de plazo para su ayuntamiento con la hembra semejan verosímilmente los quinientos años de vida atribuidos al Fénix desde Heródoto. Todavía más nos recuerda el mito de esta ave el detalle de la pira de maderas donde

39 Al-Qazwīn̄i, 'Aŷā'ib al-majlūqāt, III, 281. Al-Ibšīhī (al-Mustatraf, 389), repite el dato de los 500 años pero le atribuye tan sólo 1000 años de vida. El dato es repetido asimismo por al-Bagdādī, Jizānat al-adab. 
la 'Anq $\bar{a}$ ' se quema para dejar paso a su descendencia, si bien el Fénix, al engendrarse de sus propias cenizas, no necesita aparearse ni procrear: es un ave única. Es bastante plausible que para la época en que escribe al-Qazwīnī algunos elementos difusos de la leyenda del ave Fénix se transmitieran a la cultura árabe. Sin embargo, a la luz de los textos expuestos nada nos permite afirmar que este mito fuera recibido en su integridad o asimilado completamente.

Una tentativa de asimilación de ambas criaturas surge a medias de la etimología y de las fuentes iconográficas. Puesto que los lexicógrafos árabes medievales interpretan que 'Anqā' significa «la del largo cuello», y dado que en multitud de imágenes de la antigüedad se representa al ave Fénix en forma de garza, ibis o cisne de alargada cerviz, así las dos aves podrían haber sido tomadas por una ${ }^{40}$. Sin embargo, la etimología propuesta por la lexicografía árabe medieval tiene visos de ser, como en tantas otras ocasiones, simple etimología popular, un constructo ad hoc para salir al paso de lo que no se conoce. En efecto, las descripciones literarias de la 'Anqu' ' no dan gran importancia al pretendido detalle de su largo cuello. De hecho, en muchas ocasiones ni siquiera lo mencionan. Más probable parece la vía señalada por Nau, partiendo de Bar Hebraeus, sobre una posible transmisión al árabe a través del hebreo y del siríaco, cuya raíz ' $-n-q$, «gigante», ilustra una larga tradición acerca de criaturas colosales pertenecientes a un pasado protohistórico que remonta a Génesis 6:1-4 y a los gigantes llamados 'Änāqîm en Deuteronomio $1: 28^{41}$.

Tampoco las escasas representaciones que se conservan de la 'Anqū' se asemejan razonablemente a la iconografía tradicional del Fénix. Tal y como muestra E. Baer en su hermosa obra Sphinxes and Harpies in Medieval Islamic Art, la pareja 'Anqū' / Simurg conoció un desarrollo iconográfico y una evolución literaria muy diferentes. Las más tempranas representaciones árabes de la 'Anqū' presentan águilas bicéfalas o grifos de clara raigambre grecorromana,

${ }^{40}$ Cf. Zakhariya, "La 'anqâ"”, 136. Una variada muestra de la iconografía del Fénix puede verse en Van Den Broek, The Myth of the Phoenix, 423-464.

${ }^{41}$ Cf. Nau, "Étude sur Job", 206-7; Buendía, P., "Gigantes y macrobios en la literatura árabe", en VII Estudios de Frontera, Alcalá la Real, 2009, 167-201; Buendía y Mirones Lozano, "Se esconde en Job"; Buchanan Gray, G., A Critical and Exegetical Commentary on Numbers, New York, 1903, 141 ad 13:22; Dictionary of Deities and Demons in the Bible, Cambridge, 1999, G. Mussies, s.v. "giants". 
mientras que las miniaturas persas del Šāh Nāmah que ilustran el encuentro del ave Sīmurg con Zāl o su combate con Isfandiyār, son muy tardías en comparación con sus fuentes. Ninguna es anterior al siglo XIII, y en todas se retrata al Simurg como un pájaro gigante de larga cola multicolor. Dicha iconografía está fuertemente influida por el ave Feng Huang de la mitología china, que actúa como heraldo de la paz y la armonía y fue tradicionalmente asociada a la realeza. Baer sugiere que la representación del Feng Huang pudo transmitirse al occidente musulmán a través de las invasiones mongolas. De este modo, a partir del siglo XIV, una figura basada en el Feng Huang de larga cola multicolor se convirtió en la representación habitual del binomio 'Anqū' / Sìmurg ${ }^{42}$.

Aún así, el ave Fénix y la 'Anqā' experimentarán, cada una en su tradición cultural, un uso literario y simbólico paralelo. Por tratarse de criaturas extraordinarias, peregrinas e insólitas, pronto fueron consideradas materia fértil para la alegoría, la parénesis y las lecturas espirituales. Desde la irrupción del Fisiólogo, el Fénix se había convertido para el cristianismo en un símbolo de la resurrección de la carne y la certeza de una vida futura ${ }^{43}$. De ese modo lo vieron muchos de los padres de la Iglesia, entre ellos San Clemente ${ }^{44}$, Tertuliano ${ }^{45}$, San Ambrosio ${ }^{46}$, Orígenes ${ }^{47}$ y San Agustín ${ }^{48}$. Con la gran difusión adquirida por el género de la paradoxografía cristiana y los bestiarios en la Edad Media, esta identificación se proyectará además a las propias figuras de Cristo y de la inviolata vir-

${ }^{42}$ Baer, E., Sphinxes and Harpies in Medieval Islamic Art, Jerusalén, 1965, 41.

${ }^{43}$ Cf. McDonald, M.F., "Phoenix Redivivus", Phoenix 14 (1960), 187-206, esp. pp. 200-204; Charbonneau-Lassay, L., El bestiario de Cristo. El simbolismo animal en la Antigüedad y la Edad Media, F. Gutiérrez (trad.), Palma de Mallorca, 2001; Anglada Anfruns, El mito del Ave Fénix; Chevalier, J. y Gheerbrant, A., Dictionnaire des Symboles, París, 2000.

${ }^{44}$ Carta primera a los Corintios, XXV-XXVI, trad. esp en Anglada Anfruns, El mito del Ave Fénix, 151.

45 "De resurrectione carnis", en E. Evans (ed. y trad.), Tertullian's Treatise on the Resurrection, Londres, 1960, 13.

46 "De excessu fratris sui Satyri”, en O. Faller (ed.), Corpus Scriptorum Ecclesiasticorum Latinorum, Viena, 1955, vol. 73, lib. II, 59; trad esp. en Anglada Anfruns, El mito del Ave Fénix, 153.

${ }^{47}$ Contra Celso, D. Ruiz Bueno (trad.), Madrid, 1967, 4, 98.

48 "De anima et eius origine", en Opera Omnia di Sant'Agostino, Roma, 1981, 4, 20, 33. Cf. Van Den Broek, The Myth of the Phoenix, 364, con texto latino en n. 1. 
ginitas de la Virgen María ${ }^{49}$. De idéntico modo, la 'Anqā', que en la literatura y lexicografía árabes había sido descrita mediante la repetida fórmula "tayr ma"rūf al-ism maŷhūl al-ŷism" ${ }^{50}$, pronto se convirtió en símbolo de aquello cuya existencia se conoce pero no se puede comprobar, de lo que se busca a ciegas, de la esperanza inefable. Así, en los círculos sufíes e iluministas del Islam se desarrolló una rica literatura acerca de la ascensión celeste y el conocimiento del Uno, personificada en la figura del pájaro, y adornada frecuentemente con el símbolo de 'Anqū' Mugrib o Sìmurg ${ }^{51}$. Una de las primeras muestras de esta mística especulativa se encuentra en el Relato del pájaro (Risālat al-țayr), atribuido a Avicena ${ }^{52}$. También Ibn 'Arabī tuvo a la 'Anqā' por preciado símbolo, y sabemos que le dedicó al menos dos obras ${ }^{53}$. Se conoce igualmente otra Risālat al-țayr atribuida a Aḥmad b. Muhammad al-Gazālī (m. 1126), hermano del renombrado Algacel, que posiblemente inspiró la obra cumbre de este género, el tratado Manțiq al-tayr del poeta místico persa Farīd al-dīn 'Atțār ${ }^{54}$.

Al igual que el Cristianismo pudo explotar la figura del ave Fénix como símbolo religioso, no faltará en el Islam el uso del mito de la 'Anqa' ' con tintes de banderías políticas y pretensiones escatológicas. Nos referimos a la secta $\breve{s}^{c} \grave{l}$ llamada Sumaytiyya, que pre-

49 Fisiólogo, T. Martínez Manzano y C. Calvo Delcán (eds.), Madrid, 1999, VII, 147; Guglielmi, N., El Fisiólogo. Bestiario medieval, Madrid, 2002, IX, 75 y esp. n. 56; Malaxecheverría, I., Bestiario Medieval, Madrid, 1999, 173-9. Cf. Baxter, R., Bestiaires and their users in the Middle Ages, Londres, 1998, 1-25, 40-2.

50 «Ave de nombre conocido y de cuerpo nunca visto», o bien "Ave que existe en nombre, mas no en cuerpo»: al-Ŷawharī, al-Șihāh fí-l-luga, s.v. " "nq"; Ibn Manz̄ūr, Lisān al-'arab, s.v. " "nq"; al-Bagdādī, Jizānat al-Aḋab, VII, 135; al-Zabīdī, Tāy al-'arūs, s.v. “"nq”; al-Maydānī, Maŷma' al-amtāal, M. Abū-l-Faḍl Ibrāhīm (ed.), Beirut, 1987, I, n. ${ }^{\circ}$ 1060, 357.

${ }^{51}$ Aparte de las referencias aportadas aquí, cf. el detallado tratamiento de esta interesante cuestión en Zakhariya, "La 'anqâa", 132-138.

52 También al teósofo persa Sohravardí. Cf. Corbin, H., Avicena y el relato visionario, Barcelona, 1995, 190-191 y ss.

53 'Anqū' Mugrib fi ma'rifat jātam al-awliyā' wa-šams al-mugrib, G.T. Elmore (trad.), en Islamic Sainthood in the Fullness of Time: Ibn Al-Arabi's Book of the Fabulous Gryphon, Leiden, 1999; Risālat al-Ittihāad al-kawnī, trad franc. en D. Gril, "Le livre de l'Arbre et des quatre Oiseaux d'Ibn 'Arabī. Risālat al-ittihād al-Kawn $\vec{\imath}$ ', Annales Islamologiques, 17 (1981), 53-111; trad. ingl. en A. Jaffray, The Universal Tree and the Four Birds: Treatise on Unification, Oxford, 2006.

${ }^{54}$ Aunque dicha atribución es discutida. Cf. $E I^{2}, \mathrm{H}$. Ritter, s.vv. "al-Ghazālī”, "Aḥmad b. Muhammad” y "“Atțār, Farīd al-Dīn”; Corbin, Avicena y el relato visionario, 199 y ss.

Al-Qanțara XXXII 1, enero-junio 2011, pp. 7-26 ISSN 0211-3589 
tendía que al final de los tiempos el imām retornaría al mundo cabalgando a la 'Anqā' Mugrib y esparciendo por la Tierra un elaborado trasunto del elixir o piedra filosofal, el maravilloso «azufre rojo» ${ }^{55}$. Esta imagen guarda un estrecho paralelo con la creencia en el regreso del Profeta Muhammad cabalgando a lomos del legendario Burāq. Además, por su extrema rareza, 'Anqū' Mugrib pasó pronto a ser considerada como sinónimo de lo inexistente, de lo inverosímil. Es célebre el refrán árabe que asegura genuinamente: «Los imposibles son tres: la 'Anqā', el gūl y el amigo fiel» ${ }^{56}$. De este modo, cualquier rareza o cosa imposible de conseguir pudo considerarse un 'Anqā' Mugrib, una entelequia, una rara avis. Así, pensaba Ibn Ŷubayr que la seriedad entre las gentes de Damasco era un 'Anqā' Mugrib, porque bromeaban mucho al saludarse ${ }^{57}$. El poeta Bakr b. al-Națāạ cuenta que los deseados amores de su desdeñosa amada fueron para él "como saborear las carnes de 'Anqa', Mugrib» ${ }^{58}$. Para Abū Nuwās, en fin, el pan era el 'Anqū' Mugrib del pobre ${ }^{59}$.

Con razón, al-Ŷăhiz había afirmado a este respecto que «todas

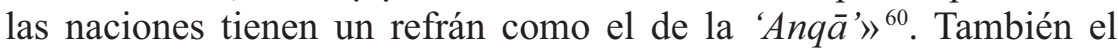
Fénix se convirtió en sinónimo de lo que no existe, y esta comparación literaria adquirió gran fortuna, sin ir más lejos en la literatura española. Así, entre otros muchos ejemplos, Tirso de Molina se lamenta del escaso pudor de las muchachas de su época:

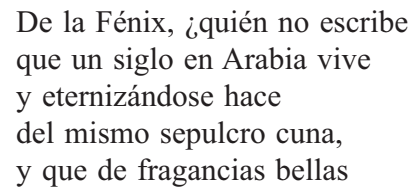

55 Véase al-Ŷāhiz, Kitāb al-tarbī' wa-l-tadwīr, Ch. Pellat (ed.), Damasco, 1955, 50, trad esp. P. Buendía, Libro de la cuadratura del círculo, Madrid, 1998, 75; al-Ŷāhiz,

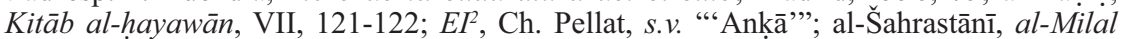
wa-l-nihal, 'Abd al-Amīr al-Muhanna y 'Alī Ḥasan Fā'ūr (eds.), Beirut, [1990], 196; $E I^{2}$, H. Halm, s.v. "Shumaytiyya" y M. Ullmann, s.v. "Kibrit".

${ }^{56}$ Al-Bagdādī, Jizānat al-adab, VII, 137. Todavía al-Ȳāhiz añadirá un cuarto imposible a la lista, el ya nombrado «azufre rojo», cf. Risāla fi-l-îidd wa-l-hazl, en Rasā'il al-Ŷăhiz, 'A.-S. Muhammad Hārūn (ed.), Beirut, 1991, I, 231-278.

${ }_{57}$ Ibn Ŷubayr, A través del Oriente, F. Maíllo (trad.), Barcelona, 1988, 345.

58 Al-Mubarrad, al-Kāmil fì-l-luga wa-l-adab, N. Zurzūr y T. Baydūn (eds.), Beirut, 1987, I, 413.

${ }^{59}$ Citado por al-Ta'ālibī, Timār al-qulūb, n. ${ }^{\circ} 729,450$.

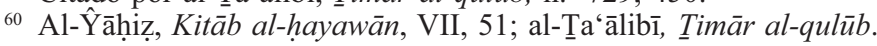




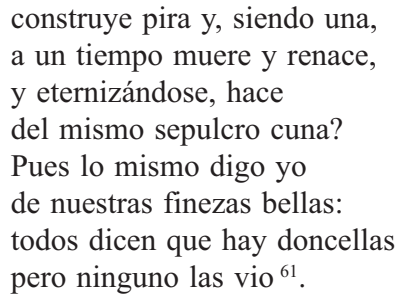

Así pues, este parece ser el último punto en que ambas leyendas comparten rumbo literario. Una bella cuarteta de Omar Jayyam puede ilustrar el panorama antes de pasar a enumerar aquellas obras árabes y persas en que encontraremos un Fénix «verdadero»:

El corazón del sabio atesora secretos, mas, como la 'Anqā', aprenderá a esconderlos.

La gota que, en la concha, del mar guarda el secreto, llegará a transformarse en perla con el tiempo ${ }^{62}$.

\section{El Ave Fénix en los textos árabes y persas}

La confirmación definitiva de que Fénix y el binomio 'Anqā' / Simurg constituyen dos mitos distintos y separados la encontramos en el ya nombrado Mantiq al-țayr, célebre apólogo místico de Farīd al-dīn 'Aț̣ār, donde los pájaros de la Creación se reúnen para buscar al «Rey de todas las aves», una de cuyas plumas es hallada en la China. Nadie ha visto jamás a esa ave soberana, cuya descripción «no tiene principio ni final»; pero la pluma encontrada encierra una majestad y pujanza tales, que «todas las almas llevan la impronta de la imagen de esa pluma». Dicho «Rey de las aves» no es otro que el majestuoso Simurg. A partir de ese momento, los pájaros del mundo deciden encontrarlo: «El deseo de tenerlo como soberano se había apoderado de ellos, sumiéndo-

${ }^{61}$ De la comedia En Madrid y en una casa, citado con profusión de otros ejemplos por Reyes, A., Obras Completas, III, México, 184 y ss. («De volatería literaria»). Cf. Deleito y Piñuela, J., La mala vida en la España de Felipe IV, Madrid, 1989, 28.

${ }^{62}$ Jayyam, O., Robaiyat, N. Amirian (ed.), Barcelona, 2002, n. ${ }^{\circ}$ 17, 129. Hemos restituido el texto persa original 'Anqa', por la traducción que ofrece la autora: "el ave Fénix". Permítasenos observar que, en este caso, aunque inexacta, la traducción es muy apropiada. 
los en la impaciencia. Hicieron proyecto de partir y decidieron viajar juntos» ${ }^{63}$.

Uno de esos pájaros en procura del rey Sìmurg es el Fénix. Según la descripción de 'Atțār, se trata de un ave admirable que habita en la India, y cuyo pico tiene agujeros a modo de flauta, por los cuales emite un maravilloso canto. El Fénix no tiene pareja, vive solo, alcanza la edad de mil años y conoce de manera precisa la fecha de su muerte. Cuando esta se acerca, atropa hojas de palmera y se cobija en ellas, emitiendo un canto melancólico por la inminencia del momento final. Dicho canto $-\mathrm{y}$ este es un dato novedoso introducido por 'Ațtār que no figura en la tradición grecolatina - es tan triste y hermoso que llega a matar a las criaturas que se reúnen para escucharlo. Entonces el Fénix bate fuertemente sus alas y produce un fuego que prende su nido y que lo consume hasta reducirlo a cenizas. Al apagarse la última chispa, de esas cenizas sale un nuevo Fénix ${ }^{64}$.

Esta verdadera ave Fénix recibe un nombre en la literatura persa: qaqnus. En su Nuzhat al-qulūb, Mustawfī le dedica una amplia descripción, en gran parte coincidente con la de 'Atțār, salvo en que ahora se trata de dos aves, macho y hembra, que a la hora de la muerte entrelazan sus picos y arden del mismo modo. Una vez consumidos, de las cenizas sale un gusano que al crecer se transforma en un nuevo Fénix ${ }^{65}$.

Los testimonios mencionados prueban que la literatura persa conocía de manera precisa el mito del Fénix tal y como se muestra en las fuentes griegas y latinas, y que no contaminó de manera notable este mito con el mucho más desarrollado (y representativo en términos históricos y mitológicos propios) del binomio 'Anqū' / Simurg. El mismo Mustawfī define en el Nuzhat al-Qulūb al ave 'Anqā' directamente como «el Sìmurg», detallando muchos de los datos más arriba expuestos sobre ella, y mostrando claramente que 'Anqu' ' y qaqnus eran dos aves distintas ${ }^{66}$.

${ }^{63}$ Cf. Attar, Farid-ud-Din, Mantic Uttaïr ou Le Langage des Oiseaux, M. Garcin de Tassy (ed. y trad.), París, 1857, 40 (de la trad); The Conference of Birds by Farid ud-Din Attar. The persian poem Mantiq Ut-tair, C.S. Nott (trad.), Londres, 1954, 13 y sigs.

${ }^{64}$ Attar, Mantic Uttaïr, cap. 26, pág. 126 y n. 1. en Garcin de Tassy, pág. 90 del texto persa, v. 2295, pp. 66-7 en Nott.

${ }^{65}$ Stephenson, The Zoological Section, 86 de la trad. y 119 del texto persa.

${ }^{66}$ Stephenson, The Zoological Section, 79-80 de la trad. y 112-14 del texto persa. 
Cabe por lo tanto preguntarse definitivamente si, aparte de las escuetas menciones marginales del mito del Fénix hechas por alQazwīn̄̄ y repetidas por al-Ibšīh en sus descripciones acerca de la presunta edad de la 'Anqā', la civilización árabe conoció cabalmente la leyenda del ave Fénix. Ciertamente, tenemos textos árabes que indican de modo expreso que la 'Anqa' ' y el Simurg son el mismo pájaro; otros que sugieren verosímilmente que, a su vez, estas dos aves son hermanas gemelas del Roc; pero no conocemos ningún texto árabe ni persa que afirme que la 'Anqā' y el qaqnus son la misma cosa. De hecho, las pocas menciones árabes de este qaqnus indican claramente que dichas leyendas estaban muy lejos de ser confudidas o identificadas. Además, la voz qaqnus, que no figura en la mayoría de los diccionarios árabes antiguos y modernos, es la usada corrientemente para designar al ave Fénix en las lenguas persa, turca y urdu ${ }^{67}$. Incluso en las literaturas de la India llega a aparecer el mito del ave Fénix con el nombre un tanto deformado, pero etimológicamente idéntico, de kakanu ${ }^{68}$.

Abū 1-'Alā' al-Ma'arrī menciona al ave llamada qaqnus en su Risālat al-Ṣāhil wa l-šăhiyy ${ }^{69}$. Según su relato, el qaqnus era un ave de muy hermosa voz que habitaba una terra incognita situada entre Alejandría y Constantinopla. Cuando presentía la muerte, cantaba de modo tan hermoso y triste que mataba a todo aquel que oía su canto. Un sabio músico griego quiso atreverse a escucharla, y para ello ingenió taponarse fuertemente los oídos, destapándoselos poco a poco a lo largo de tres días, al cabo de los cuales pudo soportar la intensidad del canto. Dicha ave qaqnus — prosigue Abū 1-'Alā'fue tragada por las aguas junto con la tierra donde habitaba, y de ella no quedó rastro alguno. Este animal recuerda poco las características esenciales del Fénix grecolatino. Su descripción coincide sólo en parte con la de 'Atțār, precisamente en el detalle novedoso del canto final que éste había introducido en su poema. Es importante señalar, en cualquier caso, que en un pasaje inmediatamente

${ }^{67}$ Steingass, F., A Comprehensive Persian-English Dictionary, Beirut, 1998 (reimpr. 1892), s.v., "qaqnus, qaqnos"; Redhouse, J.W., A Turkish and English Lexicon, Beirut, 1996 (reimpr. Estambul, 1890), s.v. "quqnus"; Platts, J.T., A Dictionary of Urdū, Classical Hindī, and English, Oxford, 1960, s.v. "qaqnus, quqnus".

${ }^{68}$ Cf. Jayasi, M.M., Padmavati, Calcuta, 1944, 129, 375-6.

${ }^{69}$ Abū l-'Alā' al-Ma'arrī, Risālat al-șāhil wa-l-šāhîy, 'Ā. 'Abd al-Rahmān bint alŠāțī’ (ed.), El Cairo, 1984, 241, 554. 
anterior de esta misma obra, al-Ma'arrī menciona a la 'Anqu' ' como un ave diferente y aparte, cuya descripción coincide totalmente con el mito tradicional árabe: un pájaro gigantesco y rapaz llevado a la extinción por Allāh ante las quejas de los profetas por causa de sus muchos estragos ${ }^{70}$. Evidentemente, tampoco para al-Ma'arrī qaqnus y 'Anq $\bar{a}$ ' eran la misma criatura.

También Avicena alude en ocasiones a este qaqnus. En su Kitāb al-hudūd le señala una nueva característica: el color blanco inmaculado $^{71}$. Al parecer, el ave qaqnus vendría a ser el paradigma de este color, el ave blanca por excelencia. Así lo repite el gran sabio persa en el Kitāb al-ǐ̌s $\bar{a} r \bar{a} t$ wa-l-tanbīhāt, con el siguiente comentario de Nașīr al-dīn al-Ṭūsī: «Es un ave llamada en griego qa'nis, que se engendra sin procrear, cuya historia es conocida, y que se pone por ejemplo de blancura, así como el cuervo de negrura» ${ }^{72}$. Es evidente que Avicena, que habría compuesto una Risālat al-țayr que sirvió de inspiración al poema de 'Atțār, y que evidentemente conocía bien el mito de 'Anqū' y Simurg, no confunde ni identifica al qaqnus con estas dos bestias aladas ${ }^{73}$.

Para este extraño nombre qaqnus se han propuesto dos etimologías. La primera acabamos de apuntarla: qaqnus sería una adaptación de la voz qa nis, cuyo $q \bar{a} f$ inicial quizá suponga la transposición de un $f \bar{a}^{\prime}$ original, correspondiente con la voz griega $\varphi$ oĩvı $\xi$. Algo parecido sugiere V. Minorsky, quien se pregunta si en el nombre qaqnus (قنتس) no se habrá producido una simple metátesis de finiqs (فنق) con la lectura errónea de $f \bar{a}$ ' por $q \bar{a} f^{74}$. Más verosimilitud ofrece la hipótesis de R. Ettinghausen, sugerida por F. Rosenthal,

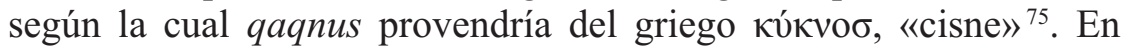
esa etimología coincide 'Alī Akbar Dehkhodā en su monumental

${ }^{70}$ Al-Ma'arrī, Risālat al-S̄āhil, 239, 552.

${ }^{71}$ Cf. Goichon, A.-M., Avicenne. Livre des Définitions, El Cairo, 1963, 97 [64], p. 39 del texto árabe; trad. ing. en Kennedy-Day, K., Books of Definitions in Islamic Philosophy, Nueva York, 2003, cap. 7 (trad.), 97, 113.

${ }^{72}$ Ibn Sinā, al-Išārāt wa-l-tanbīhāt, S. Dunyā (ed.), con comentarios de Nașīr al-dīn al-Ṭūsī, El Cairo, 1960, 244.

${ }_{73}$ Véase, por ejemplo, la mención que hace de la 'Anqā' en su Refutación de los astrólogos, apud Mehren, A.F., Vues d'Avicenne sur l'astrologie et sur le rapport de la resposabilité humaine avec le destin, Lovaina, 1885, 6.

${ }^{74}$ Minorsky, V., "The Gūrān", BSOAS, 11 (1943-6), 75-103, 97, n. 1.

75 Ettinghausen, R., Studies in Muslim Iconography, I. The Unicorn, Washington, 1950,65 , n. 26. 
Lugat Nāmah, donde además recuerda que en la mitología griega, el cisne es el animal asociado a Apolo ${ }^{76}$.

No es, sin embargo, en esa parte de la mitología griega y latina donde hemos de buscar a nuestro cisne qaqnus, sino en la leyenda acerca de sus últimos días de vida. Nos referimos al mito del canto del cisne, un ave que, al presentir su ocaso, emite el más melodioso de los cantares, con el cual anuncia su propia muerte: cantator cygnus funeris ipse sui ${ }^{77}$. Así lo inmortalizó Marcial repitiendo la primera noticia dada por Platón: «Los cisnes, cuando presienten que van a morir, cantan aquel día aún mejor que lo han hecho nunca, a causa de la alegría que tienen al ir a unirse con el dios a que ellos sirven» ${ }^{78}$; y más tarde por Aristóteles: «Son aves cantoras, pero cantan sobre todo cuando se acerca su muerte» ${ }^{79}$.

Así pues, el maravilloso y desolador canto que 'Atțār había aparejado a la leyenda del ave Fénix en el poema Manțiq al-tayr no es otro que el canto funeral del cisne, qaqnus о ки́кvoб. Así se explica también la blancura arquetípica e inmaculada que Avicena le atribuye, del mismo modo que se aclaran las alusiones a su poético y mortífero cantar referidas por Abū 1-'Alā'. El hecho de que ese último mencione al qaqnus para relatar sólo la leyenda de su canto final, sin la propia del Fénix, indica que a su vez el mito del cantar del cisne penetró marginalmente en las tradiciones literarias del Islam, para luego contaminarse de forma imprecisa con la leyenda también marginal del ave Fénix, constituyendo un curioso e interesante capítulo de la desigual y fragmentaria recepción que el legado grecolatino tuvo en la cultura árabe e islámica.

Recibido: 20/02/2009

Aceptado: 24/06/2009

76 Dehkhodā, 'A.A., Lugat Nāmah, Teherán, 1341 H., s.v. "qaqnus”.

77 Marcial, "Epigramas", en W. Heraeus-J (ed.), Martialis Epigrammata, Leipzig, 1976/82, XIII, 77.

78 Platón, Fedón, 84a-85f, P. de Azcárate (trad.), Obras completas de Platón, Madrid, 1871.

${ }^{79}$ Aristóteles, Hist. Anim., Investigación sobre los animales, C. García Gual (trad.), Madrid, 1992, 615b (libro IX). Sobre el extendido tema del canto del cisne, cf. Arnott, W.G., "Swan Songs", Greece and Rome, 24 (1977), 149-153. 